\title{
Exploration of concentration of two macro-minerals in different wild forages in relation to nutrient requirements of livestock
}

\author{
Kafeel Ahmad ${ }^{1}$, Zafar Iqbal Khan ${ }^{1}$, Muneeba Shaheen ${ }^{1}$, Farhad Mirzaei ${ }^{2 *}$, Abrar Hussain $^{3}$, \\ Fahim Arshad ${ }^{4}$, Tahir Mehmood ${ }^{5}$, Zahara Bibi $^{1}$ \\ ${ }^{1}$ Department of Biological Sciences, University of Sargodha, Sargodha, Pakistan \\ ${ }^{2}$ Livestock Production Management Department, Animal Science Research Institute of Iran, Karaj, Iran; \\ *Corresponding Author: farmir2005@gmail.com \\ ${ }^{3}$ Science and Technological Division, University of Education, Township Campus, Lahore, Pakistan \\ ${ }^{4}$ Department of Botany, University of Education, Okara Campus, Okara, Pakistan \\ ${ }^{5}$ Department of Statistics, University of Sargodha, Sargodha, Pakistan
}

Received 8 February 2013; revised 9 March 2013; accepted 1 April 2013

Copyright (C) 2013 Kafeel Ahmad et al. This is an open access article distributed under the Creative Commons Attribution License, which permits unrestricted use, distribution, and reproduction in any medium, provided the original work is properly cited.

\begin{abstract}
The composition of two macro-minerals ( $\mathrm{Ca}$ and $\mathrm{Na}$ ) was examined in soil and forages in two fields of District Sargodha, Pakistan. During winter and summer season, soil and forage samples were collected. In both seasons, Na was sufficient in soil and forages. As compared to the winter season, the $\mathrm{Na}$ and $\mathrm{Ca}$ levels in soil were considerably higher in summer season. In forages, the level of Ca was deficient than the level which is essential for livestock growth. In the pastures, grazing livestock may be deficient in these minerals as these pastures are not supplying sufficient minerals to the ruminants grazing therein. Supplementation of minerals is necessary to prevent the mineral imbalances and deficiency diseases in grazing livestock.
\end{abstract}

Keywords: Mineral Composition; Soil; Forage; Livestock

\section{INTRODUCTION}

For animals, the potential and basic constituents of food are plants, having high nutritional values and plays vital role in determining the human and animal's health. Under low input conditions, the herbs are the main source of supplying nutrients to grazing animals. The concentration of minerals considerably varies among species for livestock from toxic to inadequate [1]. Agricultural and natural forage consequences are chief source of providing minerals grazing animals in several regions of the world. The production of animals via feed depends on amount consumed by livestock and to which extent it meets the requirement of energy, vitamins, minerals and proteins [2]. The ruminants mostly feed on native grasses in dry regions, due to which they exposed to threat of mineral toxicity or deficiency $[3,4]$. For environmental and botanical purposes, the mineral analysis of plant is essential. In order to investigate the mineral requirement of ruminants and environmental contamination, the mineral uptake, especially of trace minerals can give information [5-7]. Minerals are deposited on surface of plants either through polluted areas or absorbed from soil. In many regions of world, alternative season's affects the mineral deposition of forage, which indirectly affects the grazing animals [8-10]. By prosperous reproductive programs, Seasonal forage minerals concentrations constancy could be attained [11]. It is necessary to determine the mineral contents of the new varieties of forages as these are the chief source of mineral for grazing animals [12] since the minerals are transferred to grazing animals from soil via forages.

The objectives of current study were to analyze the composition of macro-minerals ( $\mathrm{Ca}$ and $\mathrm{Na}$ ) in soil and forages and to determine where, when and to which extent the mineral problems occur as well as to ascertain the variations in minerals composition during winter and summer season in semi-arid region of Pakistan. This Knowledge will help to understand the mineral requirements of grazing ruminants in Pakistan and other Asian countries with similar ecological and 
climatic conditions.

\section{MATERIALS AND METHODS}

The research was conducted to determine the influence of sampling intervals on soil and forages mineral concentration. The samples of soil and forages were collected from different grazing places of District Sargodha, located at $32^{\circ} 08^{\prime} 00^{\prime \prime} \mathrm{N}$ and $73^{\circ} 7^{\prime} 00^{\prime \prime E}$, Punjab, Pakistan. The average rainfall is 180 to $200 \mathrm{~mm}$ in this district. At this ranch, all the pastures under natural condition are a source of agricultural production. The distance between experimental sites commonly called as feeding sites or units was $5 \mathrm{~km}$.

Forages and soil sampling was done six times: Three times, both in winter and summer season. Samples were collected very carefully, plastic gloves and clipped using steel scissors. Composite soil samples were collected under the forage using auger at the depth of $0-20 \mathrm{~cm}$. From each grazing pasture area, the sample of forages and soil were collected from four random places [13]. Samples of forages and soil were dried in an oven at $60^{\circ} \mathrm{C}$ and ground in small particles for chemical analysis, using an atomic absorption spectrophotometer.

\section{RESULTS AND DISCUSSION}

\subsection{Soil Sodium}

The mean soil Na concentration was 119.7 - 261.35 $\mathrm{mg} / \mathrm{kg}$. In winter season, the soil Na level was lowest and in summer season was highest which ranged from 136.1 - $251.4 \mathrm{mg} / \mathrm{kg}$. At site 1, the Na level was greater than those noticed at site 2. During the month of September, the Na contents were the highest and the lowest during the month of August in summer while the in February, highest value were found and lowest in January in winter. In soil, the $\mathrm{Na}$ concentration increased from July to March (Figure 1). The Na concentration in soil was well over the $62 \mathrm{mg} / \mathrm{kg}$ of critical level recorded in literature [14]. Khan et al. [10] noticed the high Na concentration in soil while working on similar research in south western Punjab, Pakistan. The concentration of Na noticed in present research was dissimilar to the values reported by different researchers in the world [15-17]. This study concluded that soil $\mathrm{Na}$ concentration was well over the critical level, thus there is no need of adding fertilizers in soil.

\subsection{Forage Sodium}

The mean values of $\mathrm{Na}$ concentration in forage ranged from 10.05 - $140.20 \mathrm{mg} / \mathrm{kg}$. In Parthenium hysterodhorus, the Na level was highest whereas in Eragrostis pilosa, the Na level was lowest. The higher concentration of $\mathrm{Na}$ in summer season and lower concentration in win- ter season is shown in Figure 2. In both seasons, Na showed irregular pattern of increase or decrease. The $\mathrm{Na}$ concentration recorded in current research was over the 0.06 percent of critical level recommended by NRC [18]. Our findings disagree with the former researches who noticed lower concentration of $\mathrm{Na}$ in forage in different regions [19-21]. Results concluded that it is not necessary to add $\mathrm{Na}^{+}$supplements (Figure 2).

\subsection{Soil Calcium}

The means values of $\mathrm{Ca}$ showed variations between seasons. Ca level abruptly increased or decreased with sampling periods and at site 1, was 112.8 - $250.6 \mathrm{mg} / \mathrm{kg}$ and was $103.2-254.7 \mathrm{mg} / \mathrm{kg}$ at site 2. The Ca level in the month of January and March was lower at site-I and site-II. In all samples of soil, the mean Ca level was well above the $72 \mathrm{mg} / \mathrm{kg}$ of critical level reported by Rhue \& Kidder [22]. The Ca level recorded in our findings was similar to the $250 \mathrm{ppm}$ of critical level recommended by Adams \& Hartoz [23]. NRA [24] \& McDowell recommended that the Ca appropriate for forages and livestock was $0.35 \%$ and $0.30 \%$. Our results concluded that the Ca level was lower in winter season than those observed in summer season. As a result, there was no need of supplementing the soil with synthetic fertilizers for forages (Figure 3).

\subsection{Calcium Forage}

The Ca level was in range of $0.68-5.34 \mathrm{mg} / \mathrm{kg}$ in summer and in winter was $0.05-7.07 \mathrm{mg} / \mathrm{kg}$. In Eragrostis pilosa, the level of Ca was lower while in Dactyloctenium aegyptium, the Ca level was higher. In all sampling periods, an abrupt change was observed in Ca level in forage. Except Dactyloctenium aegyptium, the observed Ca level in all forages was lower. In current study, it could be implicated that minerals level including Ca were high in winter season. The Ca level in forage is influenced by yield level, forage type, age factor, animal type, forage parts on which animals feed [6,25-27]. The

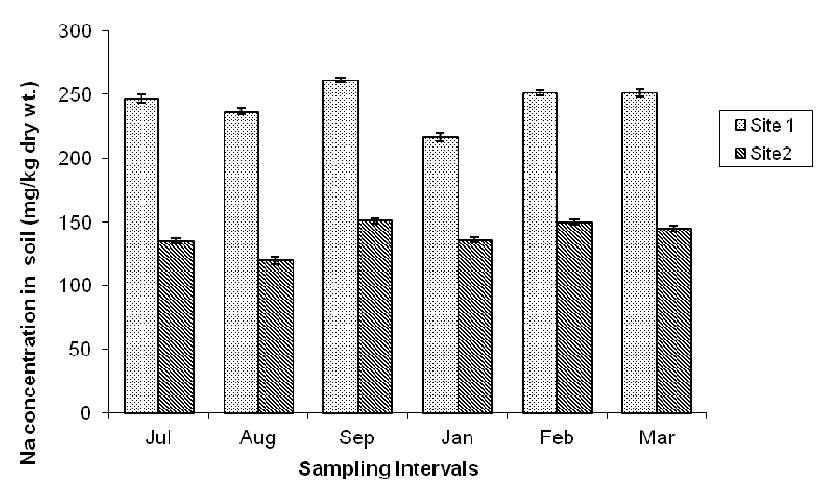

Figure 1. Fluctuations in soil Na level at different sampling intervals. 


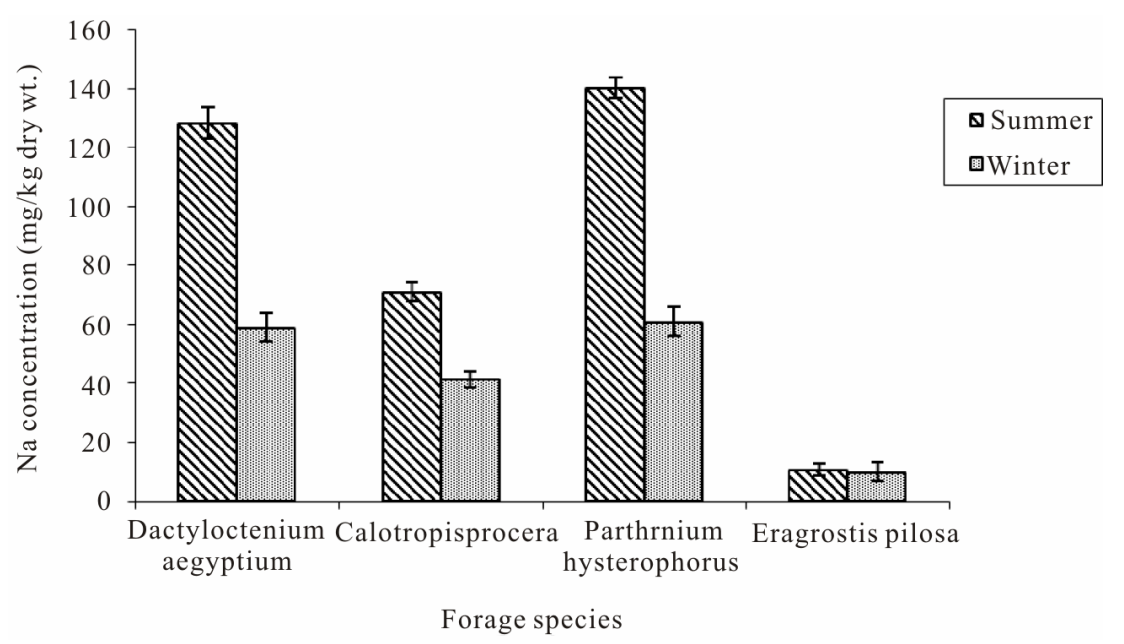

Figure 2. Sodium level fluctuations in forages at different sampling intervals.

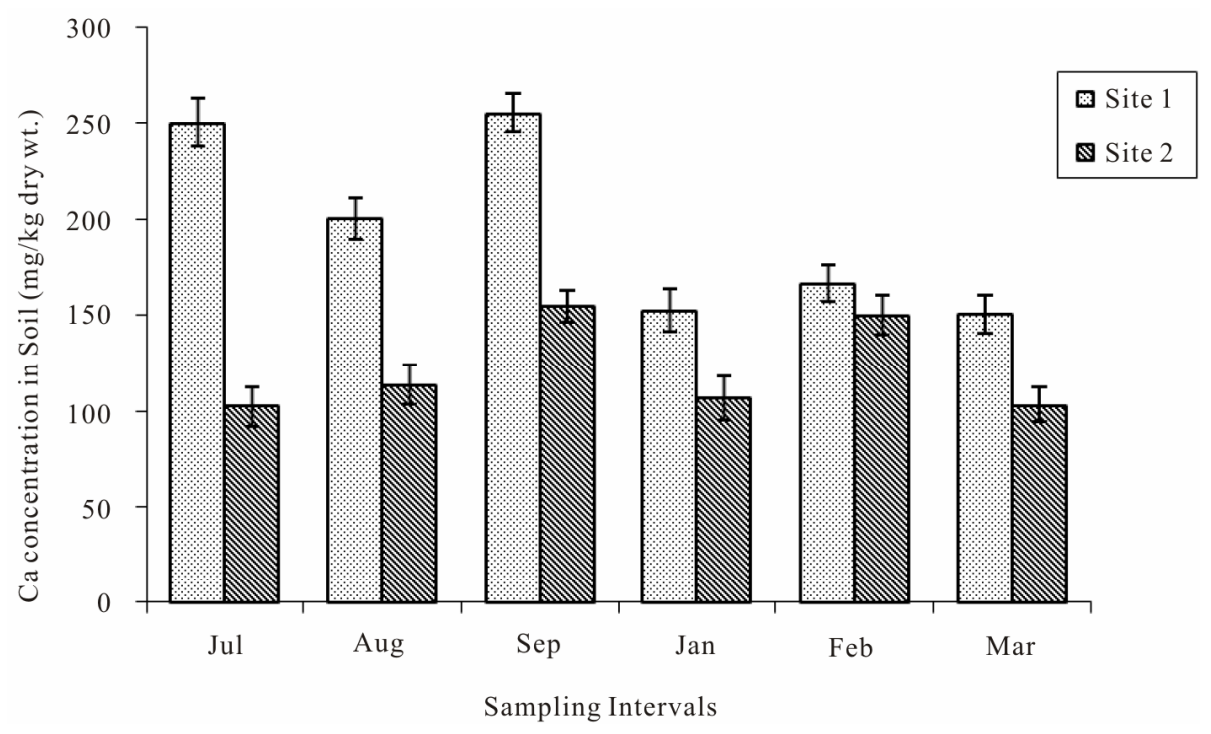

Figure 3. Fluctuations in soil Ca level at different sampling intervals.

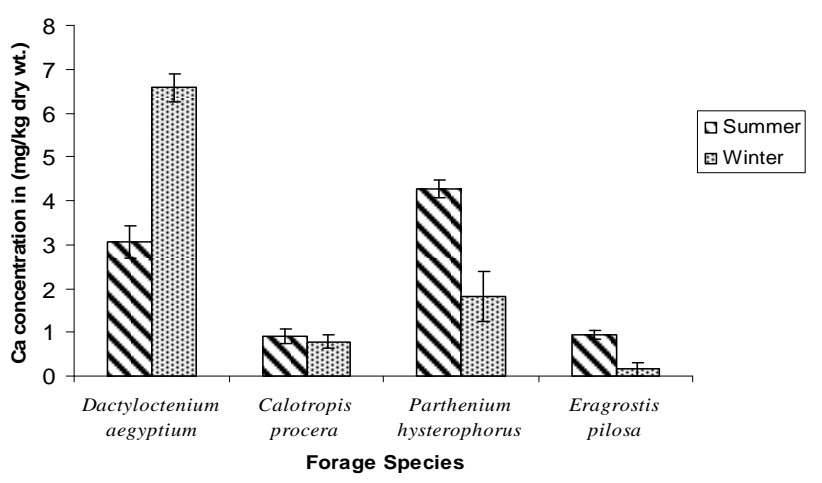

Figure 4. Fluctuations in forages Ca level at different sampling intervals.

permissible level of Ca forage was 2 - $6 \mathrm{~g} / \mathrm{kg}$ as recommended by $[6,28,29]$. The Ca level observed in present study was lower than the level of $2.5 \mathrm{~g} / \mathrm{kg}$ demonstrated by Skyes \& Field [29]. As compared to other animals, the more Ca level is essential for lactating animals. Comparable to older animals, young animals need high level of Ca due to higher growth factor. Our results concluded that, in all forage species, Ca level was below the requirements of ruminants, so Ca deficiency could be fulfilled by adding fertilizers (Figure 4).

\section{CONCLUSION}

It is necessary to determine the mineral contents of the new varieties of forages as these are the chief source of mineral for grazing animals since the minerals are transferred from soil to grazing animals via forages growing therein. It is concluded that grazing ruminants may deficient in these minerals as these pastures are not supplying sufficient minerals to the ruminants grazing therein. Supplementation of minerals is necessary to prevent the 
mineral imbalances and deficiency diseases in grazing livestock

\section{REFERENCES}

[1] Grusak, M.A. and Dellapenna, D. (1999) Improving the nutrient composition of plants to enhance human nutrition and health. Annual Review of Plant Physiology and Plant Molecular Biology, 50, 133-161.

doi:10.1146/annurev.arplant.50.1.133

[2] Minson, D.J. (1990) Forage in ruminants. Academic Press Inc., San Diego.

[3] Fujihara, T., Motsui, T., Hayashi, S., Robel, A.Y., Scrra, A.B., Cruz, L.C. and Shimizu, H. (1992) Mineral status of grazing Philippine goats in Luzon Island. Asian-Australian Journal of Animal Sciences, 5, 389-395.

[4] Fujihara, T., Hosoda, C. and Matsui, T. (1995) Mineral status of grazing sheep in the dry area of Midland China. Australian Journal of Animal Sciences, 8, 179-186.

[5] Yusuf, A.A., Arowola, T.A. and Bamgbose, O. (2003) Cadmium, copper, and nickel levels in vegetables from industrial and residual areas of Logos City, Nigeria. Food and Chemical Toxicology, 41, 375-378.

[6] Khan, Z.I., Hussain, A., Ashraf, M. and McDowell, L.R. (2006) Mineral status of soils and forages in South Western Punjab-Pakistan: Micro-minerals. Asian-Australian Journal of Animal Sciences, 19, 1139-1147.

[7] Khan, Z.I., Ashraf, M., Javed, I. and Ermidou-Pollet, S. (2007) Transfer of sodium from soil and forage to sheep and goats grazing in a semiarid region of Pakistan. Influence of the seasons. Trace Elements and Electrolytes, 24, 49-54.

[8] Arizmendi-Maldonado, D., McDowell, L.R., Sinclair, T.R., Mislevy, P., Martin, F.G. and Wilkinson, N.S. (2001) Mineral concentrations in four tropical forages as affected by increasing day length. I. Macro minerals. Communications in Soil Science and Plant Analysis, 33, 1991-2000. doi:10.1081/CSS-120004837

[9] Khan, Z.I., Hussain, A., Ashraf, M., Ashraf, M.Y., Valeem, E.E. and Ahmad, M.S. (2004) Soil and forage (trace elements) status of a grazing pasture in the semiarid region of Pakistan. Pakistan Journal of Botany, 4, 851-856.

[10] Khan Z.I., Ashraf, M., Hussain, A. and McDowell, L.R. (2005) Seasonal variation of trace elements in a semiarid veld pasture. Communications in Soil Science and Plant Analysis, 37, 1471-1484. doi:10.1080/00103620600585914

[11] Mislevy, P., Sinclair, T. and Ray, J.D. (1999) Improving forage productivity during late fall and early winter by making grass less sensitive to short days. Agronomy Department Bulletin No. 748, Department of Agronomy, University of Florida, Gainseville.

[12] McDowell, L.R. (1992) Minerals in animal and human nutrition. Academic Press, San Diego.

[13] Anonymous (1979) Methods of mineral analysis for plant and animal tissues-laboratory manual. Institute of Food and Agricultural Sciences, University of Florida, Center for Tropical Agriculture.

[14] Prabowo, A., McDowell, L.R., Wilkinson, N.S., Wilcox, C.J. and Conrad, J.H. (1990) Mineral status of grazing cattle in South Sulawesi, Indonesia; I. Macrominerals. Asian-Australian Journal of Animal Sciences, 4, 111-120.

[15] Espinoza, J.E., McDowell, L.R., Wilkinson, N.S., Conrad, J.H. and Martin, F.G. (1991) Monthly variation of forage and soil minerals in Central Florida. II. Trace minerals. Communications in Soil Science and Plant Analysis, 22, 1137-1149. doi:10.1080/00103629109368480

[16] Khan, Z.I., Ahmed, K., Ashraf, M., Valeem, E.E. and Javed, I. (2008) A comparative study on mineral status of blood plasma of small ruminants and Pastures in Punjab, Pakistan. Pakistan Journal of Botany, 41, 67-72.

[17] National Research Council (1984) Nutrient requirements of beef cattle. 6th Revised Edition, Nutrient Requirements of Domestic Animals, No. 4, National Academy of Science, National Research Council, Washington DC.

[18] Rehman, A., Kincad, M.M. and Elzubejr, P. (1998) Mineral deficiencies in grazing cattle in Kardofan and Darfur regions in the eastern Sudan. Tropical Animal Health and Production, 30, 123-135. doi:10.1023/A:1005051902115

[19] Tiffany, M.E., McDowell. L.R., Connor. G., Nguyen, H., Martin, F.G., Wilkinson, N.S. and Katzowitz, N.A. (2001) Effects of residual and re-applied biosolids on forage and soil concentrations over a grazing season in north Florida. II. Microminerals. Communications in Soil Science and Plant Analysis, 32, 2211-2226.

[20] Khan, Z.I., Ahmed, K., Ashraf, M., Valeem, E.E. and McDowell, L.R. (2009) Mineral status of forage and its relationship with that of plasma of farm animals in Southern Punjab, Pakistan. Pakistan. Journal of Botany, 41, 67-72.

[21] Adams, F. and Hartzog, D.L. (1980) The nature of yield responses of Florunner peanuts to lime. Peanut Science, 7, 120-123. doi:10.3146/i0095-3679-7-2-15

[22] Rhue, R.D. and Kidder, G. (1983) Analytical procedures used by the IFAS extension soil laboratory and the interpretation of results. Soil Science Department, University of Florida, Gainesville.

[23] National Research Council (1996) Nutrient requirements of beef cattle. 7th Edition, National Academy Press, Washington DC.

[24] McDowell, L.R. (1985) Nutrition of grazing ruminants in warm climates. Academic Press, New York.

[25] Dierenfeld, E.S., Toit, R. and Braselton, W.E. (1995) Nutrient composition of selected browses consumed by black rhinoceros in the Zimbabwe valley. Zimbabwe Journal of Zoo and Wildlife Medicine, 26, 220-230.

[26] Ndebele, N., Mtimuni, J.P., Mpofu, I.D.T., Makuza, S. and Mumba, P. (2005) The status of selected minerals in soils, forage and beef cattle tissues in a semi-arid region of Zimbabwe. Tropical Animal Health and Production, 37, 381-393.

[27] Anonymous (1980) Analytical methods for atomic-absorption spectrophotometry. Perkin-Elmer, Norwalk Connecticut.

[28] Anonymous (1985) Nutrient requirements of domestic 
animals. In: National Research Council, Nutrient Requirements of Beef Cattle. 6th Revised Edition, National Academy Science, Washington DC.

[29] Sykes, A.R. and Field, A.C. (1972) Effect of dietary deficiencies of energy, protein and calcium on the pregnant ewe. III. Some observations on the use of biochemical pa- rameters in controlling under-nutrition during pregnancy and on the efficiency of energy, utilization of energy and protein for the foetal growth. Journal of. Agricultural Science (Cambridge), 78, 127-133.

doi:10.1017/S0021859600087785 